\title{
Wanted: A few good ideas
}

The United States Marine Corps, back in the days before women joined the fighting forces, had a recruiting slogan that said, "Wanted: A Few Good Men." The concept could be profitably adapted by the international research community in a world of diminishing financial resources but persistently increasing need of good ideas to solve the intransigent challenges in medical science.

The evidence that we need new ideas is everywhere around us. In Japan, government ministries are trying to 'kick-start' gene therapy research - particularly the development of new vectors. Added evidence of France's commitment to research is a promise to spend $\$ 51 \mathrm{mil}-$ lion during the next two years on a new national strategy for the life sciences. Britain, too, has taken up the cause through its 'technology foresight' venture, which is earmarking $\$ 106$ million for so-called priority initiatives. (Nature Medicine 1, 291, 293, 294; 1995.)

And in the United States, the National Institutes of Health (NIH) is awash in new committees to review (among other things) the infrastructure supporting gene therapy, clinical research and peer review, and the quality of the research programmes of each of the NIH's individual institutes at its Bethesda, Maryland, headquarters. (A blistering review of the intramural program of the National Cancer Institute (NCI), once the undisputed leader in the development of new cancer therapy, suggests not only that the NCI's in-house budget be cut (see p. 615), but also alleges that its clinical training is so poor that medical fellows receive "insufficient exposure . . . to standard oncologic practice."). Varmus's multiple advisory committees, comprised largely of the best and the brightest of the biomedical research establishment, are essentially taking another crack at overall assessment of NIH. Varmus's predecessor, Bernadine Healy, attempted a similar but politically ill-fated assessment when she ordered NIH to write a Strategic Plan for its future.

All this studying, planning, and campaigning, going on all over the world, suggests that we have a drought in the midst of intellectual plenty. No one in her right mind would deny that, during the past two decades, new avenues of research were opened through the discovery of recombinant DNA and that the depth of understanding of molecular processes at work in dozens of diseases is unprecedented in human history. Why, then, the need to dissect the research infrastructure to the same level of 'molecular' detail?
What is needed - dare one say it? - is a breakthrough. And the path most likely to lead us where we want to go is support, worldwide, of 'innovative' ideas. Tinkering at the margins will not do the job.

In a little noticed, but astonishing revealing paragraph in the widely unread NIH Strategic Plan of 1992, there is one really good idea. It was, quite simply this - the creation of a new route through the grant process. Called "High Risk/Innovative Research," some brave soul among the plan's authors suggested a program to "support research that is considered high risk and whose exploration has the potential for high payoff. Investigators would submit an abbreviated application, stressing the novel aspects of the research."

This is at once a marvelous idea and a dishearteningly frank indictment of the current system. It is commonly said that the world is rich in grant applications that are worthy of funding and that the only real solution is to find, somehow, enough money to fund them all. But privately, research leaders admit that funding agencies in all countries tend to favor those most likely to succeed, however modestly.

Of course, it is not governments alone that are uneasy with the current state of affairs. The private sector as well is plugging away for one cause or another. Take, for instance, the National Race for the Cure, a private Texas-based charity that celebrated its sixth anniversary last month. On Saturday 17 June, thousands of women (and some men) paid $\$ 17$ to run past the Washington monument and around the U.S. Capitol to draw attention to the need to cure breast cancer. (The entry fee went to the cost of organizing the race, not research.) The race is meant to support research, education, and treatment by attracting publicity and corporate donors.

It is a fine idea. The $5 \mathrm{~K}$ run (or walk for the less vigorous) surely contributed either to the fitness of the racers or the incomes of orthopaedic surgeons. But it will not lead to a cure for breast cancer any more than will other charity events or me-too research that merely advances the field a millimeter or so.

We do not need a race for the cure. We need a race to find scientific leaders bold enough to put risk and innovation - not only good but original ideas - at the top of the research agenda; leaders who are willing to take the flak that would go with distributing limited resources accordingly.

Barbara J. Culliton 